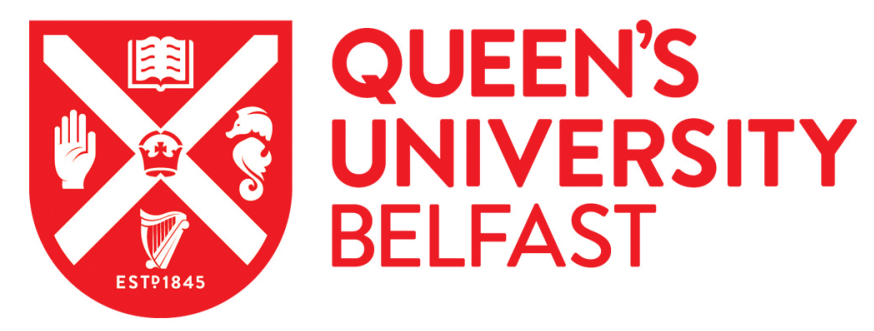

\title{
Uncovering long term relationships between oil prices and the economy: A time-varying cointegration analysis
}

Gogolin, F., Kearney, F., Lucey, B. M., Peat, M., \& Vigne, S. A. (2018). Uncovering long term relationships between oil prices and the economy: A time-varying cointegration analysis. Energy Economics, 76, 584-593. https://doi.org/10.1016/j.eneco.2018.10.002

\section{Published in: \\ Energy Economics}

\section{Document Version:}

Peer reviewed version

Queen's University Belfast - Research Portal:

Link to publication record in Queen's University Belfast Research Portal

\section{Publisher rights}

Copyright 2018 Elsevier B.V. All rights reserved.

This manuscript is distributed under a Creative Commons Attribution-NonCommercial-NoDerivs License

(https://creativecommons.org/licenses/by-nc-nd/4.0/), which permits distribution and reproduction for non-commercial purposes, provided the author and source are cited.

\section{General rights}

Copyright for the publications made accessible via the Queen's University Belfast Research Portal is retained by the author(s) and / or other copyright owners and it is a condition of accessing these publications that users recognise and abide by the legal requirements associated with these rights.

Take down policy

The Research Portal is Queen's institutional repository that provides access to Queen's research output. Every effort has been made to ensure that content in the Research Portal does not infringe any person's rights, or applicable UK laws. If you discover content in the Research Portal that you believe breaches copyright or violates any law, please contact openaccess@qub.ac.uk. 


\title{
Uncovering long term relationships between oil prices and the economy: A time-varying cointegration analysis
}

\author{
Fabian Gogolin \\ Leeds University Business School, University of Leeds, LS6 1AN, UK \\ Fearghal Kearney \\ Queen's Management School, Queen's University Belfast, BT9 5EE, UK \\ Brian M. Lucey \\ Trinity Business School, Trinity College Dublin, Dublin 2, Ireland 83 \\ University of Sydney Business School, Sydney, New South Wales 2006, Australia \\ Maurice Peat \\ University of Sydney Business School, Sydney, New South Wales 2006, Australia \\ Samuel A. Vigne \\ Queen's Management School, Queen's University Belfast, BT9 5EE, UK
}

\begin{abstract}
Establishing the relation between oil price movements and macroeconomic performance is of great importance for firms and policymakers, alike. Prior studies established this relation using the assumption that the long-run relation is intertemporally constant. However, there is much recent evidence demonstrating that this assumption may not hold in practice. To address this issue and go beyond the restrictive time-invariant environment, we employ the use of the time-varying cointegration framework of Bierens and Martins (2010). We present evidence of the long-run oil-economy relation evolving over the 1974-2015 period, with major events such as the Gulf War and the financialisation of commodity markets proving to be driving forces across the U.S., European and G7 economies considered.
\end{abstract}

Keywords: Marcoeconomy, oil prices, WTI Oil, Brent Oil, long-run

Email addresses: f.gogolin@leeds.ac.uk (Fabian Gogolin), f.kearney@qub.ac.uk (Fearghal Kearney), blucey@tcd.ie (Brian M. Lucey), maurice.peat@sydney.edu.au (Maurice Peat), s.vigne@qub.ac.uk (Samuel A. Vigne) 


\section{Introduction}

As energy is such an integral part of any modern functioning economy, there is a broad consensus that oil price fluctuations impact both global economic growth and financial markets (Brown and Yücel, 2002, Jones et al., 2004, Hamilton, 2009, Lucey et al., 2018). This paper studies the long-term relationship between oil price movements and economic activity, proxied by GDP. Somewhat surprisingly, there is a debate on the directional nature of this relationship. Early studies put forward an inverse relationship between the two variables, however this dynamic does not necessarily hold in the long term (Hamilton, 1983, Burbidge and Harrison, 1984, Gisser and Goodwin, 1986). Given fundamental shifts in long term supply and demand side forces of commodity markets, we hypothesise the existence of structural breaks in the relationship and suggest that these must be modelled explicitly. This is particularly prevalent in the case of oil markets as they are subject to periods of pressures not explained by classical supply-side effects (Brown and Yücel, 2002).

In a closely related study to ours Lardic and Mignon (2008) find that economic activity has distinct reactions to positive and negative oil price shocks. We extend and update their study by also implementing the asymmetric cointegration approach and by additionally focusing on the time-varying nature of a relationship driven by variations in monetary policy, political instability and changing energy product consumption patterns. To capture this relationship we employ the use of the time-varying cointegration technique of Bierens and Martins (2010). As opposed to assuming a fixed relationship between economic activity and oil, we instead model gradual and smooth changes in the relationship. We firstly provide statistical evidence rejecting the standard constant coefficient cointegration model, instead supporting the notion that a time-varying cointegration relationship exists between crude oil prices and economic activity. An advantage of our time-varying cointegration approach over other nonlinear cointegration techniques, most notably over some Markov Switching models, is that we do not need to impose the restriction of there being a fixed number of regimes or a specific nonlinear functional form a priori. Our methodology is particularly useful for comparing specifications in terms of their stability as it nests the usual time invariant model. In this sense, we are performing a model evaluation and selection exercise similar to the encompassing test principle of Mizon and

Richard (1986), rather than just testing for structural changes in the param- 
eters. As additional robustness checks we also incorporate a multiple breaks test, as proposed by Bai and Perron (2003), the nonlinear ARDL model of Shin et al. (2014), and the partial cointegration analysis of Clegg and Krauss (2018).

Furthermore, motivated by contrasting investor focus across regions, we consider both WTI and Brent oil prices, to ascertain if the link between oil prices and economic activity varies by product. Indeed, both Brent and WTI are global light sweet crude oil benchmarks, however, they exhibit individual behaviour as the spread between the two products is not constant. In fact the spread between Brent and WTI can vary wildly, as explained by Choi and Hammoudeh (2009) and Ajmi et al. (2014). Ajmi et al. (2014) outline that this is driven by WTI being priced from its storage location in Cushing, Oklahoma, from where it cannot be exported internationally. For this reason it is said that the price of Brent oil is a superior proxy of prevalent global demand and supply side forces.

There is both theoretical and empirical evidence for believing that parameters in macroeconomic models may vary over time. Prior literature has reported that underlying functions and relations in the monetary model are subject to parameter instabilities or regime changes (Clarida et al., 2000, Kim and Nelson, 2006, Bierens and Martins, 2010). For instance, Clarida et al. (2000) found that different periods of monetary policy characterised the regimes. This phenomenon led Kim and Nelson (2006) to apply a timevarying parameter model that highlighted different periods of monetary policy rules between the 1960s and 1990s. Furthermore, Park and Park (2013) state that cointegration coefficients can vary over time when it is difficult to disentangle the fundamentals from unobservable components such as risk premia. Specific to oil markets, Ajmi et al. (2014) and Boldanov et al. (2016a) provide empirical evidence that the relationship between oil and the related variable of stock market performance is indeed time-varying.

Our paper is organised as follows. Section 2 recalls the main transmission channels through which oil prices may impact GDP. Section 3 briefly presents the econometric framework considered, with Section 4 outlining the dataset considered. Section 5 is devoted to an empirical analysis of the link between oil prices and GDP in the long run in the U.S., G7, and European countries, with Section 6 proposing alternative frameworks, and Section 7 concluding the paper. 


\section{Transmission Channels and Time-Varying Relationship}

Lardic and Mignon (2008) outline various transmission channels through which oil prices can impact economic activity; through the cost of production, through PPP, through interest rates, through inflation, through consumption and investment, and through unemployment. We now briefly explore each of these transmission channels. Firstly, through the cost of production (Zhang and Ji (2018)). Oil as a raw material in production. An increase in the price of oil increases the costs of production, which detrimentally affects output levels and in turn economic growth (Barro, 1984, Brown and Yucel, 1999). Secondly, through purchasing power parity. An increase in the price of oil leads to the terms of trade for the oil importers being less favourable. This in turn leads to a lower purchasing power for both firm and households in these oil importing countries (Dohner, 1981). Thirdly, through interest rates. An increase in oil prices can lead to an increase in money demand due to the real balance effect (Pierce et al., 1974, Mork, 1994). This increased money demand can cause central banks to increase the cost of money, i.e., the interest rate, which in turn will hit economic activity (Brown and Yücel, 2002). Fourthly, through inflation. An increase in oil prices generates inflation in the economy. Inflation is often met in turn by increased wage demand, further compounding the effect in a price-wages loop. Fifthly, through downward pressure on consumption and investment. The mechanism is that an increase in oil prices leads to a reduction in disposable income which in turn reduces consumption. It also increases a firm's costs, which hits investment. Finally, through unemployment. If an elevated oil price level is sustained it can change firms' structure and give rise to unemployment.

Ajmi et al. (2014), Boldanov et al. (2016a), Bašta and Molnár (2018), and Roubaud and Arouri (2018) have shown that correlation between oil and the related stock market performance are responsive to major economic and geopolitical events (see Antonakakis et al. (2017), Antonakakis et al. (2017), and Fang et al. (2018)), such as the early-2000 recession, the 9/11 terrorist attacks, and the Global Financial Crisis of 2007-2009. Results upgraded by Zhang (2017) who considers the effect of oil price shocks and uncovers occasional yet very significant effects of oil price shocks on stock markets, Chen and Lv (2015), Zheng and Su (2017) and Bouri et al. (2017) for China specifically (see Sanusi and Ahmad (2016) and Diaz and de Gracia (2017) for the effects of oil price shocks on stock returns of oil and gas corporations), and Boldanov et al. (2016b), Ftiti et al. (2016), Jammazi et al. (2017), Ji 
et al. (2018), and Ji et al. (2018) who consider a time-varying methodology in studying the relationship between oil price shocks and stock market returns in the BRICs (see Pönkä (2016), Luo and Qin (2017), Ping et al. (2018), Mensi et al. (2018), and Bouri et al. (2018) or Evgenidis (2018) for the Euro Area and Caporin et al. (2018) for the S\&P 500 index) ${ }^{1}$. Boldanov et al. (2016a) focus on six major oil-importing and oil-exporting countries with a Diag-BEKK model being employed over the January 2000 to December 2014. We consider both WTI and Brent oil prices, motivated by contrasting investor focus across regions, to ascertain if the link between oil prices and economic activity varies by product. This approach aligns with Ajmi et al. (2014) who investigate nonlinear causal relationships between oil prices and MENA stock markets, finding that it is more pronounced in the case of Brent oil prices. They use the nonlinear causality test of Kyrtsou and Labys (2006), and find that oil prices and MENA stock markets interact in a nonlinear manner. Our study differs however, in that we focus our attention on economic activity as represented by the national accounts as opposed to stock market performance. We also implement our analysis from a long-run perspective through the use of the time-varying cointegration model that accounts for the intertemporal adjustments in the oil-economy transmission channels outlined above.

\section{Empirical Approach}

The basis of our empirical analysis is a $p$ dimensional vector autoregressive (VAR) model with Gaussian errors:

$$
X_{t}=\Psi_{1} X_{t-1}+\ldots+\Psi_{k} X_{t-k}+\Phi D_{t}+\epsilon_{t}, \quad t=1, \ldots, T
$$

where $X_{0}, \ldots, X_{k+1}$ are fixed, $\epsilon_{1}, \ldots, \epsilon_{T}$ are $i i d$ and $N_{p}(0, \Omega)$, and $D_{t}$ is a vector of deterministic variables specified as a restricted trend; allowing for the cointegration relation to be trend-stationary and have a non-zero intercept.

\subsection{Cointegration}

Cointegration can be identified by reformulating Equation 1 in the error correction form:

$$
\Delta X_{t}=\Pi X_{t-1}+\Gamma_{1} \Delta X_{t-1}+\ldots+\Gamma_{k-1} \Delta X_{t-k+1}+\Phi D_{t}+\epsilon_{t}, \quad t=1, \ldots, T
$$

\footnotetext{
${ }^{1} \mathrm{~A}$ recent overview of the literature on the relationship between oil and stock market returns can be found in Smyth and Narayan (2018)
} 
with $\Pi=\sum_{i=1}^{k} \Psi_{i}-I_{p}$ and $\Gamma_{i}=-\sum_{i=i+1}^{k} \Psi_{i}$, while the properties of Equation 2 are determined by:

$$
\Psi(z)=(1-z) I_{p}-\Pi_{z}-\sum_{i=1}^{k-1} \Gamma_{i}(1-z)
$$

where if $z=1$ is a root, then $\Pi$ has a reduced rank $r<p$, given that $|\Psi(1)|=|\Pi|=0$.

In the case of $z=1$, Equation 3 implies that $\Pi$ can be written as $\Pi=\alpha \beta^{\prime}$, where $\alpha$ and $\beta$ are $p * r$ matrices of full column rank. Cointegration exists if the reduced rank condition of the $\Pi$ matrix is given as follows:

$$
H_{r}: \Pi=\alpha \beta^{\prime}
$$

implying that the processes $\Delta X_{t}$ and $\beta^{\prime} X_{t}$ are stationary, whereas $X_{t}$ is nonstationary, assuming that a technical condition on the derivative of $\Psi$ is satisfied. $^{2}$

The likelihood ratio test of the hypothesis of $r$ cointegrating relations against the unrestricted alternative is given by the trace statistic:

$$
-2 \log Q(H(r) \mid H(p))=-T \sum_{i=r+1}^{p}\left(1-\hat{\lambda}_{i}\right)
$$

Note that the null hypothesis is that the rank is $r$, meaning that the system has $p-r$ unit-roots. Determining the cointegration rank is done by testing a sequence of hypotheses starting with the hypothesis of $p$ unitroots, which if rejected implies that $\lambda_{1}>0$, followed by the hypotheses that $\lambda_{2}=\lambda_{3}=\ldots=\lambda_{p}=0$. The evolution of the trace statistic over time can be determined through utilising the average of recursive and backward recursive estimation that relies on a base sample determined by the Akaike Information Criterion (Akaike (1974)).

If cointegration between oil and the GDP series exists, then $r=1$, so that $\Pi X_{t-1}$ is given by:

$$
\Pi X_{t-1}=\alpha \beta^{\prime} X_{t-1}=\left(\begin{array}{c}
\alpha_{1} \\
\alpha_{2} \\
\alpha_{3}
\end{array}\right)\left(\beta_{1} x_{1_{t-1}}+\beta_{2} x_{2_{t-1}}+\beta_{3} x_{3_{t-1}}\right)
$$

\footnotetext{
${ }^{2}$ Stationarity test results are available on demand.
} 


\subsection{Time-variation in the cointegration relationship}

Bierens and Martins (2010) base their model on Equation 2 and propose a time-varying Vector Error Correction Model (VECM) of order $p$ in which the cointegration vectors are smooth functions of time, and that for some $t$ there are fixed $r<k$ linearly independent columns of the time-varying $k * r$ matrix $\beta_{t}=\left(\beta_{1_{t}}, \ldots, \beta_{r_{t}}\right)$ :

$$
\Delta X_{t}=\sum_{j=1}^{p-1} \Xi_{j} \Delta X_{t-j}+\alpha \beta_{t}^{\prime} X_{t-1}+\gamma_{0}+\epsilon_{t}, \quad t=1, \ldots, T
$$

where $\epsilon_{t} \sim N_{k}(0, \Theta)$, while $\Theta$ and $\Xi_{j}$ are $k * k$ matrices. $\alpha$ is a fixed $k * r$ matrix (with $r$ representing the cointegration rank of the system), and $\beta_{t}$ is a time-varying $k * r$ matrix of rank $r$.

The null hypothesis of time-invariant cointegration $\left(\Pi_{t}^{\prime}=\Pi^{\prime}=\alpha \beta_{t}^{\prime}\right)$ is tested against the alternative hypothesis of time-varying cointegration of the type $\Pi_{t}^{\prime}=\alpha \beta_{t}^{\prime}$.

Bierens and Martins (2010) assume standard smoothness and orthonormality conditions, and argue that the parameters of vector $\beta_{t}$ can be approximated by a finite sum of Chebyshev time polynomials $P_{i, T}(t)$ of decreasing smoothness for some fixed $m$ :

$$
\beta_{t}=\beta_{m}(t / T)=\sum_{i=0}^{m} \xi_{i, T} P_{i, T}(t), \quad t=1, \ldots, T
$$

where $1 \leq m<T-1 . \quad \xi_{i, T}=\frac{1}{T} \sum_{t=1}^{T} \beta_{T} P_{i, T}(t)$ for $i=0, \ldots, T-1$ are unknown $k * r$ matrices.

If you substitute Equation 8 into Equation 7, the following is obtained:

$$
\Delta X_{t}=\sum_{j=1}^{p-1} \Xi_{j} \Delta_{t-j}+\alpha \xi^{\prime} X_{t-1}^{(m)}+\gamma_{0}+\epsilon_{t}
$$

where $\xi^{\prime}=\left(\xi_{0}^{\prime}, \xi_{1}^{\prime}, \ldots, \xi_{m}^{\prime}\right)$ is an $r *(m+1) k$ matrix of rank $r$.

Finally, $X_{t-1}^{(m)}$ is defined by:

$$
X_{t-1}^{(m)}=\left(X_{t-1}^{\prime}, P_{1, T}(t) X_{t-1}^{\prime}, P_{2, T}(t) X_{t-1}^{\prime}, \ldots, P_{m, T}(t) X_{t-1}^{\prime}\right)^{\prime}
$$


where the null hypothesis of time-invariant cointegration corresponds to $\xi^{\prime}=$ $\left(\beta^{\prime}, O_{r, k . m}\right)$, so that $\xi^{\prime} X_{t-1}^{(m)}=\beta^{\prime} X_{t-1}^{(m)}$ with $X_{t-1}^{(0)}=X_{t-1}$, which can be tested with a likelihood ratio test. ${ }^{3}$

\subsection{Asymmetric Cointegration}

Furthermore, we employ the asymmetric cointegration approach of Shin et al. (2014), which allows us to compare our results more directly to those of Lardic and Mignon (2008). The Nonlinear Auto Regressive Distributed Lags (NARDL) approach of Shin et al. (2014) is capable of simultaneously modelling asymmetries in both the long-run relationship and the pattern of dynamic adjustments; therefore allowing us to disentangle positive and negative long-run relationships and also model sudden shocks in the data.

Based on the partial sum decomposition used to model asymmetric cointegration (Schorderet (2001)), Shin et al. (2014) assume that the dependent variable can be explained by positive and negative changes of $x_{t}$, so that:

$$
y_{t}=\beta^{+} x_{t}^{+}+\beta^{-} x_{t}^{-}+u_{t}
$$

where $y_{t}$ and $x_{t}$ are scalar $\mathrm{I}(1)$ variables. $x_{t}$ can be decomposed so that $x_{t}=x_{0}+x_{t}^{+}+x_{t}^{-}$, where:

$$
\begin{aligned}
& x_{t}^{+}=\sum_{j=1}^{t} \Delta x_{j}^{+}=\sum_{j=1}^{t} \max \left(\Delta x_{j}, 0\right) \\
& x_{t}^{-}=\sum_{j=1}^{t} \Delta x_{j}^{-}=\sum_{j=1}^{t} \min \left(\Delta x_{j}, 0\right)
\end{aligned}
$$

and asymmetric cointegration is given when $z_{t}$ defined as:

$$
z_{t}=\beta_{0}^{+} y_{t}^{+}+\beta_{0}^{-} y_{t}^{-}+\beta_{1}^{+} x_{t}^{+}+\beta_{1}^{-} x_{t}^{-}
$$

is stationary (Schorderet (2003)).

Finally, the distinction between positive and negative changes in the rate of growth of the dependent variable is obtained by decomposing $x_{t}$ into $x_{t}^{+}$

\footnotetext{
${ }^{3}$ More details can be found in Bampinas and Panagiotidis (2015), Lucey et al. (2017), and Bilgin et al. (2018).
} 
and $x_{t}^{-}$around a threshold of zero through a NARDL model of the form (Shin et al. (2014)):

$$
y_{t}=\sum_{j=1}^{p} \phi_{j} y_{t-j}+\sum_{j=0}^{q}\left(\Theta_{j}^{+^{\prime}} x_{t-j}^{+}+\Theta_{j}^{-^{\prime}} x_{t-j}^{-}\right)+\epsilon_{t}
$$

where $x_{t}$ is a $k * 1$ vector of multiple regressors, so that $x_{t}=x_{0}+x_{t}^{+}+x_{t}^{-} . \phi_{j}$ is the autoregressive parameter, with $\Theta_{j}^{+}$and $\Theta_{j}^{-}$the asymmetric distributedlag parameters, and finally, $\epsilon_{t}$ is an iid process with zero mean and constant variance $\sigma^{2}$.

\subsection{Partial Cointegration}

As a robustness test, we apply the partial cointegration methodology proposed by Clegg and Krauss (2018) which models the spread series as the sum of both a mean-reverting component and a random walk component; allowing for a weakening of the traditional concept of cointegration.

Formally, the two series $X_{1}=\left(X_{1, t}\right)_{t \in T}$ and $X_{2}=\left(X_{2, t}\right)_{t \in T}$ are partially cointegrated if $\beta, \rho, \sigma_{M}$, and $\sigma_{R}$ can be found via a maximum likelihood method and satisfy the following conditions:

$$
\begin{aligned}
X_{2, t} & =\beta X_{1, t}+W_{t} \\
W_{t} & =M_{t}+R_{t} \\
M_{t} & =\rho M_{t-1}+\epsilon_{M, t} \quad \epsilon_{M, t} \sim \mathcal{N}\left(0, \sigma_{M}^{2}\right) \\
R_{t} & =R_{t-1}+\epsilon_{R, t} \quad \epsilon_{R, t} \sim \mathcal{N}\left(0, \sigma_{R}^{2}\right)
\end{aligned}
$$

where $\beta \in \mathbb{R}$ is a parameter, and $\rho \in(-1,1)$ is the $\operatorname{AR}(1)$ coefficient. $\epsilon_{M, t}$ and $\epsilon_{R, t}$ follow mutually independent Gaussian white noise processes with expectation zero and variances $\sigma_{M}^{2}, \sigma_{R}^{2} \in \mathbb{R}_{0}^{+}$.

\section{Data}

In line with Lardic and Mignon (2008) our aim is to study the long-term relationship between oil prices and GDP not only in the U.S., but also in Europe and across the G7 nations. We extend their study both in time period, across countries, and methodologically to surface new findings. To this end we obtain quarterly data for the sample period Q1 1970 to Q4 2015 from the OECD for US GDP, G7 GDP, Europe GDP, and WTI and Brent Oil prices. The G7 includes: Canada, France, Germany, Italy, Japan, the United 
Kingdom, and the United States. Europe is to include: Austria, Belgium, Finland, France, Germany, Ireland, Italy, the Netherlands, Norway, Portugal, Spain, Sweden, and the United Kingdom. Table 1 offers a snapshot of the descriptive statistics related to the variables under investigation.

\section{Insert Table 1 about here}

We can see that the mean price of WTI and Brent oil products differs, with Brent oil showing a greater level of volatility over the sample period. It must be noted here however that due to data availability the WTI sample only begins in 1982. The GDP levels for each of the regions are of the same order of magnitude, with the individual country U.S. region displaying the largest level of variation, over the cross-country G7 and European regions. None of the variables in the panel are normally distributed as indicated by the skewness, kurtosis, and Jarque-Bera statistics. However, the methodology of time-varying cointegration allows for modelling behaviour of variables that are not normally distributed. Figure 1 shows us the evolution of each of our series over time.

\section{Insert Figure 1 about here}

Oil-specific and global economic shocks can be seen in this graph, with the Gulf War in the early 1990s and the Global Financial Crisis of 2007-2009 both prominent.

\section{Main Findings}

As the Johansen (1991) test is a special time-invariant case of our Bierens and Martins (2010) time-varying cointegration analysis, we firstly produce Johansen (1991) test results, as displayed in Table 2.

\section{Insert Table 2 about here}

In comparison with the Bierens and Martins (2010) approach we employ later on, Johansen (1991) is restrictive in that it assumes that the cointegrating vector is constant over time and that the adjustment is linear. As we 
sequentially focus on the relation between sets of two variables individually, the maximum rank of the cointegrating relationship is 1. For this reason, the null hypotheses specified is that of the rank $r$ of the cointegrating relationship being a maximum value of 0 or 1 . As can be seen in Table 2 our main finding is that there is a long-run relation, between the price of Brent and each of the individual region's GDP, and between WTI and both the USA and G7. This indicates that the price of WTI does not drive European economic activity, a result that highlights the regional focus on each oil product brought about by the ban on the exportation of WTI oil internationally (see Ajmi, El-montasser, Hammoudeh and Nguyen, 2014).

Table 3 provides us with the significance results derived from imposing the Chebyshev time polynomial approximation on the time-invariant cointegrating vector $\beta$.

\section{Insert Table 3 about here}

This approximation allows us to move from a time-invariant environment to a time-varying modelling environment. As detailed in Section 3, Bierens and Martins (2010) prove that under standard smoothness and orthonormality conditions the time-varying parameters can be approximated for a given $m$ by a sum of Chebyshev time polynomials. A time-varying relationship is indicated by $\mathrm{m}>0$, with $m=0$ indicating a standard time-invariant long-run cointegrating relationship. Table 3 shows that in all the cases we consider $m \geq 2$. These results are produced using the assumed rank of 1 as retrieved from Table 2. We again highlight in Table 3 that there is no long-run relationship between WTI and the European economies, as was established in Table 2. For this reason we do not have a cointegrating vector to approximate using the Chebyshev Time Polynomials.

Trace statistic results derived from the Bierens and Martins (2010) timevarying cointegration analysis are presented in Figure 2, indicating that the long-run relation between WTI oil price and economic activity is present across large periods of our sample, for both the US and G7 nations.

\section{Insert Figure 2 about here}

The trace statistic is used here as opposed to the eigenvalue test in line with Cheung and Lai (1993) and Bampinas and Panagiotidis (2015) who 
state that the trace statistic shows a greater robustness to residual skewness and excess kurtosis. As outlined in Section 3 the trace test statistic results are scaled by the associated $95 \%$ critical value and standardised to zero so that a value of less than zero can be taken as an indication of a cointegrating relationship being present and a value of greater than zero indicating that no cointegrating relationship exists. We observe negative scaled trace statistics across the 1990 to early 2000s period. Again, as indicated by Table 2 there is no significant relationship between European GDP and WTI. A strengthening of the long-run relationship between WTI and macroeconomic activity is observed during the oil price spike of 1990 and the associated Gulf War. During this period the economic fate of both the US and many of the G7 nations was dependent on the very volatile prices of oil. This aligns with asymmetric response observed by Lardic and Mignon (2008), who conclude that oil price rises have a greater impact on economic activity than oil price declines.

Boldanov et al. (2016a) identify the early 2000s recession coupled with the 9/11 terrorist attack as a catalyst for the cointegrating relationship between oil and equity markets breaking down. However, we also argue that this phenomenon partially aligns with the financialisation of commodity markets observed in the early 2000s, as outlined by Adams and Glück (2015) (and references therein). The financialisation of these markets came about when actors that were not normally present in the trading of commodities entered the marketplace. Whereas commodities were traditionally seen to hedge movements in equity markets, the presence of both commercials and speculators caused them to be traded like any other asset class, similar to equities. The result of this is apparent here as the transmission mechanism and linkages between the oil price and economic activity identified earlier break down. It can be inferred that speculators have driven the price of oil away from its economic fundamentals, see, for example Gogolin and Kearney (2016) and Ji and Zhang (2018). The presence of a common stochastic trend between the WTI price variable and G7 economic activity lasts longer than between the US based WTI price and US economic activity with a significant relationship observed starting in the late 1980s until roughly 2007, which could be attributed to a earlier drive towards financialisation in the US. Moreover, what is also apparent from the graph is the complete breakdown of the cointegrating relationship as a result of the 2007-2009 Global Financial Crisis, with the scaled trace statistic peaking during this period.

We now turn our attention to the Brent oil-economy relation, motivated 
in part by Ajmi et al. (2014) who provide evidence that nonlinear causality between the related stock market variable is even stronger in the case of Brent. We can see from Figure 3 that cointegrating relationships exist between the economic activity in each of the regions and the price of Brent oil.

\section{Insert Figure 3 about here}

The stark contrast with the WTI-economy relation is that European GDP has a long-run relationship with Brent. This lasts for roughly the same length of time as the relationship between the other economic regions and the oil price, roughly, 1990 to 2004. We interpret the presence of a cointegrating relationship between Brent and economic activity, in comparison with WTI and economic activity, as an indication that the Brent product was not traded in as speculative a fashion as WTI. Furthermore, the recession of the early 2000s and the 9/11 terrorist attack impacted the US greater than the G7 nations, as can be seen by certain members not experiencing a recession, such as the UK and Canada. For this reason we hypothesise that the fundamental transmission mechanisms did not break down as abruptly in the G7 economies as in the US.

As a robustness check to further identify the need to consider the timevarying nature of the relationship we conduct the Bai and Perron (2003) multiple breaks test.

\section{Insert Table 4 about here}

We establish the presence of three regimes, with structural breaks identified in the late 80s for WTI, in line with the oil crisis and growing political unrest in the oil producing gulf region, and the early 2000s in line with the financialisation of commodity markets. The breaks identified here broadly correspond with those derived from the Bierens and Martins (2010) trace statistic as shown in Figures 2 and 3.

\section{Alternative Frameworks}

In this section we present the results of two alternative approaches for modelling the long-run relationship between oil and the macroeconomy. This 
first approach is the asymmetric modelling approach of Shin et al. (2014). We consider this framework to produce an analysis comparative with the asymmetric relation tests of Lardic and Mignon (2008). The second framework we present here is the recent methodological innovation of partial cointegration analysis as considered by Clegg and Kraus (2018). This approach is well suited to our problem as it allows for both a random walk and mean reverting component in the cointegrating relation. In the previous section we outlined intertemporal deviations from the long term relation with the partial cointegration analysis employed here to seek further insight into this dynamic.

Methodological detail of the nonlinear ARDL approach of Shin et al. (2014) is outlined in Section 3.3, with the results presented in Table 5.

\section{Insert Table 5 about here}

From these we can firstly see that based on the F-test, long-run asymmetry is present in the relationship between the price of WTI and all considered regions. This indicates that the impact of WTI price changes on economic activity differs between positive and negative price moves. We also observe a limitation of the approach as no significance is found when we focus individually on the positive and negative price moves for WTI. Overall, there is no long-run asymmetry observed for Brent oil, indicating a more straightforward relationship between the European focused product and economic growth across the world. Lardic and Mignon (2008) outline a number of possible explanations for the asymmetric dynamic observed here in the longrun WTI relationship. These include monetary policy, adjustment costs, impact of uncertainty on investment and asymmetry inherent in the pricing of refined oil products. The implications of this identified asymmetry for investors, managers, and policy makers, include a need to explicitly model positive and negative WTI price movements separately, before implementing business decisions and trading strategies.

We now introduce the results of the partial cointegration analysis of Clegg and Krauss (2018) outlined in Section 3.4. The partial cointegration framework is less restrictive than traditional cointegration in that it allows for the presence of both permanent and transitory shocks. Clegg and Krauss (2018) exploit this to show multiple examples in finance and economics where cointegrating relationships are not found but partial cointegration is in fact 
uncovered. Motivated by this we seek to identify if a partial cointegrating relationship exists in our oil-economy relationship. The results presented in Table 6 indicate that we fail to reject all hypotheses of no partial cointegration; there is no evidence of a partial cointegrating relation across all regions and oil types.

\section{Insert Table 6 about here}

To understand these results we first note that despite Clegg and Krauss (2018) being less restrictive than traditional cointegration, a major distinction between it and our previously considered Bierens and Martins (2010) approach is that beyond the modelling of random walk and autoregressive residuals, Clegg and Krauss (2018) do not explicitly account for intertemporal variation in the relationship. Given that the results do not uncover significant instances of partial cointegration, we conclude that Clegg and Krauss (2018)'s combination of transitory and permanent shocks is insufficient in explaining the intertemporal variations we uncovered previously. This finding validates our decision to primarily focus on the results of the Bierens and Martins (2010) time-varying approach.

\section{Conclusion}

The majority of prior work that examines if a long-term relationship exists between oil prices and GDP is based on the traditional linear cointegration framework. Motivated by Boldanov et al. (2016a) and Ajmi et al. (2014), who outline that the relationship between oil and stock market performance, a related economic performance indicator, is not stable over time, we also seek to explicitly identify and model the time-varying component. Going beyond the time-invariant Johansen (1991) approach adopted in previous studies we allow for smooth transitions in the cointegrating vector, using the framework proposed by Bierens and Martins (2010). Our approach establishes that there is indeed a time-varying component to the long-run relation between the oil price and macroeconomic activity, as measured by GDPs across a wide variety of regions.

We establish through both the analysis of the temporal properties of the scaled trace statistic and the Bai and Perron (2003) multiple breaks test that the oil price spike associated with the 1990 Gulf War caused a strengthening 
of the transmission mechanism between oil and macroeconomic performance. This could be due to the political uncertainty leading to an oil price spike that causes a deterioration in terms of trade for the oil importing countries, as highlighted by Dohner (1981) and Lardic and Mignon (2008). This effectively causes wealth to be transferred from the oil-importing countries (e.g., G7, U.S., Europe) to the oil-exporting countries, of which many prominent exporters are concentrated in this Gulf region. This increased interconnectedness is seen in terms of oil prices having a greater impact on economic activity. Boldanov et al. (2016a) also highlight the heterogenous behaviour between oil-importing and oil-exporting countries. Moreover, the opposite effect is observed in the early 2000s as a result of the recession and 9/11 terrorist attack, combined with the increased financialisation of commodity markets. This increase in the number of speculators active in the oil market appears to destabilise the fundamental linkages. This destabilisation is further exacerbated by the global financial crisis of 2007-2009. Given this new regime, a significant long-run relation may in fact never return. Loungani (1986) and Lardic and Mignon (2008) hypothesise that such a fundamental and long-lasting shift in the pricing of oil, can cause the shifting of production to less oil intensive operations, thus reducing the link transmission mechanism between oil prices and economic activity.

Overall, the results we uncover highlight the need for firms, investors, and policy makers to be cognisant of the time varying nature of the relationship between oil and the macroeconomy. More specifically, a key implication of our results for investors is the need to adopt flexible approaches when taking positions either directly in oil markets or in oil related sectors, such as those outlined in Section 2. For instance, pricing models for such securities need to explicitly account for the time-varying dependency, with the naïve adoption of linear modelling approaches possibly misinforming speculative trading strategies. The main takeaway from our results for firms and policy makers is the need to incorporate the dynamic relationship into their business projections, including expansion/contraction initiatives, cashflow and finance costing plans, and future resource allocations. Furthermore, the possible move away from less oil intensive operations, borne not only out of traditionally cited environmental concerns, but also the financialisation of commodity markets, as we highlight, further emphasises the need for policy makers to adapt their approach; which may include a strategy to reduce their overall reliance on oil. Finally, our results highlight that incorporating multiple structural breaks is of utmost importance for firms who are pricing 
bespoke oil market linked hedging strategies.

Possible future directions for research in this area could include the adoption of a framework that combines both an asymmetric decomposition and a time-varying cointegration approach to simultaneously establish how oil price rises/declines might asymmetrically impact economic growth, and how that dynamic might evolve over time. 


\section{Bibliography}

Adams, Z. and T. Glück (2015). Financialization in commodity markets: A passing trend or the new normal? Journal of Banking $\&$ Finance 60, 93-111.

Ajmi, A. N., G. El-montasser, S. Hammoudeh, and D. K. Nguyen (2014). Oil prices and mena stock markets: New evidence from nonlinear and asymmetric causalities during and after the crisis period. Applied Economics 46(18), 2167-2177.

Akaike, H. (1974). A New Look at the Statistical Model Identification. IEEE Transactions on Automatic Control 19(6), 716-723.

Antonakakis, N., I. Chatziantoniou, and G. Filis (2017). Oil shocks and stock markets: Dynamic connectedness under the prism of recent geopolitical and economic unrest. International Review of Financial Analysis 50, 126.

Antonakakis, N., R. Gupta, C. Kollias, and S. Papadamou (2017). Geopolitical risks and the oil-stock nexus over 1899-2016. Finance Research Letters 23, 165-173.

Bai, J. and P. Perron (2003). Computation and analysis of multiple structural change models. Journal of Applied Econometrics 18(1), 1-22.

Bampinas, G. and T. Panagiotidis (2015). Are gold and silver a hedge against inflation? a two century perspective. International Review of Financial Analysis 41, 267-276.

Barro, R. J. (1984). Macroeconomics. Wiley.

Bašta, M. and P. Molnár (2018). Oil market volatility and stock market volatility. Finance Research Letters 26, 204-214.

Bierens, H. J. and L. F. Martins (2010). Time-varying cointegration. Econometric Theory 26(5), 1453-1490.

Bilgin, M. H., F. Gogolin, M. C. K. Lau, and S. A. Vigne (2018, mar). Timevariation in the relationship between white precious metals and inflation: A cross-country analysis. Journal of International Financial Markets, Institutions and Money. 
Boldanov, R., S. Degiannakis, and G. Filis (2016a). Time-varying correlation between oil and stock market volatilities: Evidence from oil-importing and oil-exporting countries. International Review of Financial Analysis 48, 209-220.

Boldanov, R., S. Degiannakis, and G. Filis (2016b). Time-varying correlation between oil and stock market volatilities: Evidence from oil-importing and oil-exporting countries. International Review of Financial Analysis 48, 209-220.

Bouri, E., Q. Chen, D. Lien, and X. Lv (2017). Causality between oil prices and the stock market in China: The relevance of the reformed oil product pricing mechanism. International Review of Economics 86 Finance 48, $34-48$.

Bouri, E., D. Lien, D. Roubaud, and S. J. H. Shahzad (2018). Directional predictability of implied volatility: From crude oil to developed and emerging stock markets. Finance Research Letters Forthcoming.

Brown, S. P. and M. K. Yucel (1999). Oil prices and us aggregate economic activity: a question of neutrality. Economic \& Financial Review, 16.

Brown, S. P. and M. K. Yücel (2002). Energy prices and aggregate economic activity: an interpretative survey. The Quarterly Review of Economics and Finance 42(2), 193-208.

Burbidge, J. and A. Harrison (1984). Testing for the effects of oil-price rises using vector autoregressions. International Economic Review, 459-484.

Caporin, M., C.-L. Chang, and M. McAleer (2018). Are the S\&P 500 index and crude oil, natural gas and ethanol futures related for intra-day data? International Review of Economics 8 Finance Forthcoming.

Chen, Q. and X. Lv (2015). The extreme-value dependence between the crude oil price and Chinese stock markets. International Review of Economics \& Finance 39, 121-132.

Cheung, Y.-W. and K. S. Lai (1993). Finite-sample sizes of johansen's likelihood ratio tests for cointegration. Oxford Bulletin of Economics and statistics 55(3), 313-328. 
Choi, K. and S. Hammoudeh (2009). Long memory in oil and refined products markets. The Energy Journal, 97-116.

Clarida, R., J. Gali, and M. Gertler (2000). Monetary policy rules and macroeconomic stability: evidence and some theory. The Quarterly journal of economics 115(1), 147-180.

Clegg, M. and C. Krauss (2018). Pairs trading with partial cointegration. Quantitative Finance 18(1), 121-138.

Diaz, E. M. and F. P. de Gracia (2017). Oil price shocks and stock returns of oil and gas corporations. Finance Research Letters 20, 75-80.

Dohner, R. S. (1981). Energy prices, economic activity and inflation: survey of issues and results. Energy prices, inflation and economic activity. Ballinger, Cambridge, $M A$.

Evgenidis, A. (2018). Do all oil price shocks have the same impact? Evidence from the euro area. Finance Research Letters 26, 150-155.

Fang, L., B. Chen, H. Yu, and C. Xiong (2018). The effect of economic policy uncertainty on the long-run correlation between crude oil and the U.S. stock markets. Finance Research Letters 24, 56-63.

Ftiti, Z., K. Guesmi, and I. Abid (2016). Oil price and stock market comovement: What can we learn from time-scale approaches? International Review of Financial Analysis 46, 266-280.

Gisser, M. and T. H. Goodwin (1986). Crude oil and the macroeconomy: Tests of some popular notions: Note. Journal of Money, Credit and Banking 18(1), 95-103.

Gogolin, F. and F. Kearney (2016). Does speculation impact what factors determine oil futures prices? Economics Letters 144, 119-122.

Hamilton, J. D. (1983). Oil and the macroeconomy since world war ii. Journal of political economy $91(2), 228-248$.

Hamilton, J. D. (2009). Causes and consequences of the oil shock of 2007-08. Technical report, National Bureau of Economic Research. 
Jammazi, R., R. Ferrer, F. Jareño, and S. J. H. Shahzad (2017). Time-varying causality between crude oil and stock markets: What can we learn from a multiscale perspective? International Review of Economics $\&$ Finance 49, 453-483.

Ji, Q., E. Bouri, and D. Roubaud (2018). Dynamic network of implied volatility transmission among US equities, strategic commodities, and BRICs equities. International Review of Financial Analysis 5\%, 1-12.

Ji, Q., B.-Y. Liu, W.-L. Zhao, and Y. Fan (2018). Modelling dynamic dependence and risk spillover between all oil price shocks and stock market returns in the BRICs. International Review of Financial Analysis Forthcoming.

Ji, Q. and D. Zhang (2018). China's crude oil futures: Introduction and some stylized facts. Finance Research Letters Forthcoming.

Johansen, S. (1991). Estimation and Hypothesis Testing of Cointegration Vectors in Gaussian Vector Autoregressive Models. Econometrica 59(6), $1551-1580$.

Jones, D. W., P. N. Leiby, and I. K. Paik (2004). Oil price shocks and the macroeconomy: what has been learned since 1996. The Energy Journal, $1-32$.

Kim, C.-J. and C. R. Nelson (2006). Estimation of a forward-looking monetary policy rule: A time-varying parameter model using ex post data. Journal of Monetary Economics 53(8), 1949-1966.

Kyrtsou, C. and W. C. Labys (2006). Evidence for chaotic dependence between us inflation and commodity prices. Journal of Macroeconomics 28(1), 256-266.

Lardic, S. and V. Mignon (2008). Oil prices and economic activity: An asymmetric cointegration approach. Energy Economics 30(3), 847-855.

Loungani, P. (1986). Oil price shocks and the dispersion hypothesis. The Review of Economics and Statistics, 536-539.

Lucey, B. M., S. S. Sharma, and S. A. Vigne (2017). Gold and inflation(s) A time-varying relationship. Economic Modelling 67, 88-101. 
Lucey, B. M., S. A. Vigne, L. Ballester, L. Barbopoulos, J. Brzeszczynski, O. Carchano, N. Dimic, V. Fernandez, F. Gogolin, A. González-Urteaga, J. W. Goodell, P. Helbing, R. Ichev, F. Kearney, E. Laing, C. J. Larkin, A. Lindblad, I. Lončarski, K. C. Ly, M. Marinč, R. J. McGee, F. McGroarty, C. Neville, M. O'Hagan-Luff, V. Piljak, A. Sevic, X. Sheng, D. Stafylas, A. Urquhart, R. Versteeg, A. N. Vu, S. Wolfe, L. Yarovaya, and A. Zaghini (2018). Future directions in international financial integration research - A crowdsourced perspective. International Review of Financial Analysis 55, 35-49.

Luo, X. and S. Qin (2017). Oil price uncertainty and Chinese stock returns: New evidence from the oil volatility index. Finance Research Letters 20, $29-34$.

Mensi, W., B. Hkiri, K. H. Al-Yahyaee, and S. H. Kang (2018). Analyzing timefrequency co-movements across gold and oil prices with BRICS stock markets: A VaR based on wavelet approach. International Review of Economics \&3 Finance 54, 74-102.

Mizon, G. E. and J.-F. Richard (1986). The Encompassing Principle and its Application to Testing Non-Nested Hypotheses. Econometrica 54(3), 657-678.

Mork, K. A. (1994). Business cycles and the oil market. The Energy Journal, $15-38$.

Park, C. and S. Park (2013). Exchange rate predictability and a monetary model with time-varying cointegration coefficients. Journal of International Money and Finance 37, 394-410.

Pierce, J. L., J. J. Enzler, D. I. Fand, and R. Gordon (1974). The effects of external inflationary shocks. Brookings Papers on Economic Activity 1974(1), 13-61.

Ping, L., Z. Ziyi, Y. Tianna, and Z. Qingchao (2018). The relationship among China's fuel oil spot, futures and stock markets. Finance Research Letters 24, 151-162.

Pönkä, H. (2016). Real oil prices and the international sign predictability of stock returns. Finance Research Letters 17, 79-87. 
Roubaud, D. and M. Arouri (2018). Oil prices, exchange rates and stock markets under uncertainty and regime-switching. Finance Research Letters Forthcoming.

Sanusi, M. S. and F. Ahmad (2016). Modelling oil and gas stock returns using multi factor asset pricing model including oil price exposure. Finance Research Letters 18, 89-99.

Schorderet, Y. (2001). Revisiting Okun's Law: An Hysteretic Perspective.

Schorderet, Y. (2003). Asymmetric Cointegration.

Shin, Y., B. Yu, and M. Greenwood-Nimmo (2014). Modelling asymmetric cointegration and dynamic multipliers in a nonlinear ardl framework. In Festschrift in Honor of Peter Schmidt, pp. 281-314. Springer.

Smyth, R. and P. K. Narayan (2018). What do we know about oil prices and stock returns? International Review of Financial Analysis 57, 148-156.

Zhang, D. (2017). Oil shocks and stock markets revisited: Measuring connectedness from a global perspective. Energy Economics 62, 323-333.

Zhang, D. and Q. Ji (2018). Further evidence on the debate of oil-gas price decoupling: A long memory approach. Energy Policy 113, 68-75.

Zheng, X. and D. Su (2017). Impacts of oil price shocks on Chinese stock market liquidity. International Review of Economics \& Finance 50, 136174 . 
Figure 1: Graph of GDP in Trillions of $\$$ against the $\$$ Price of Brent and WTI

35

30

20

15

10

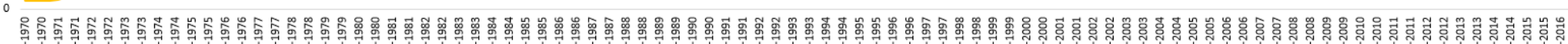

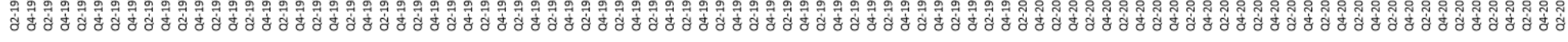


Figure 2: Scaled trace statistic ofWTI cointegration parameters

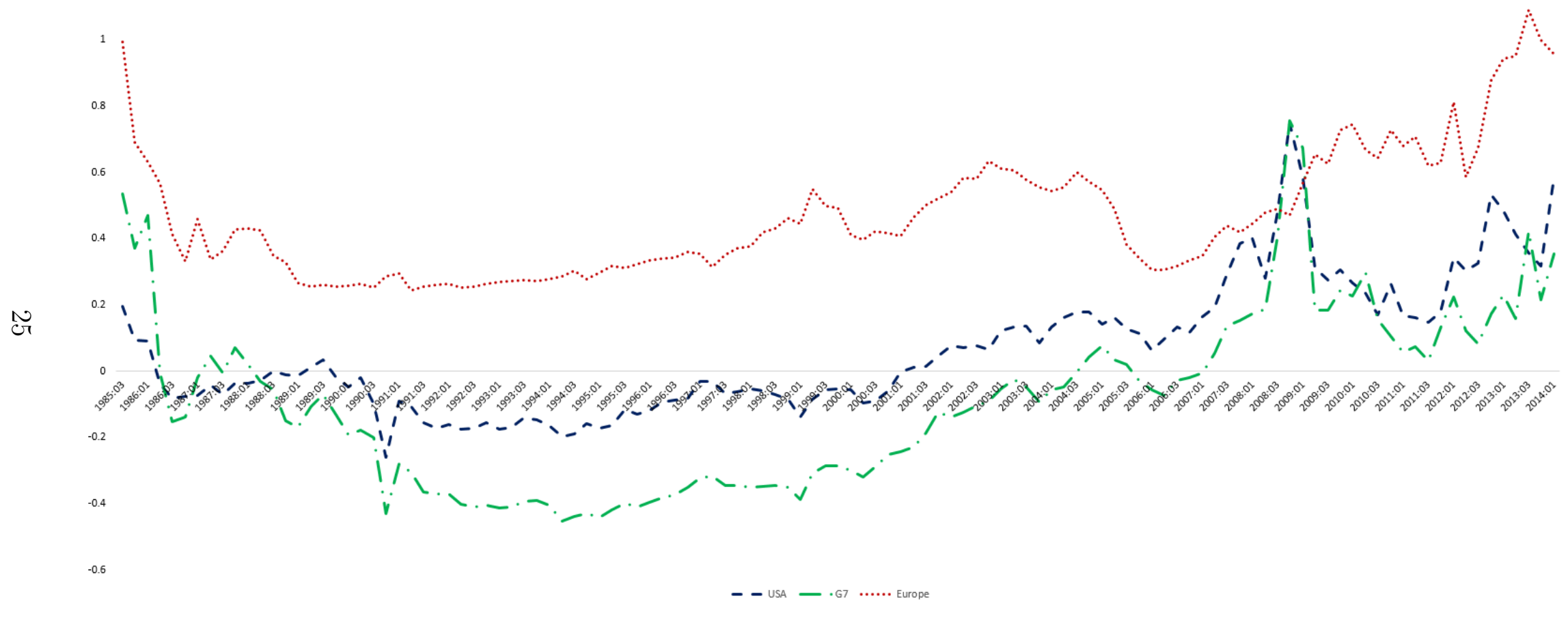

Note: A positive trace statistic indicates that WTI oil is not cointegrated with the respective GDP series. The trace statistic is scaled by the $5 \%$ critical value and generated using both recursive and backwards recursive estimation. 
Figure 3: Scaled trace statistic of cointegration parameters - Brent

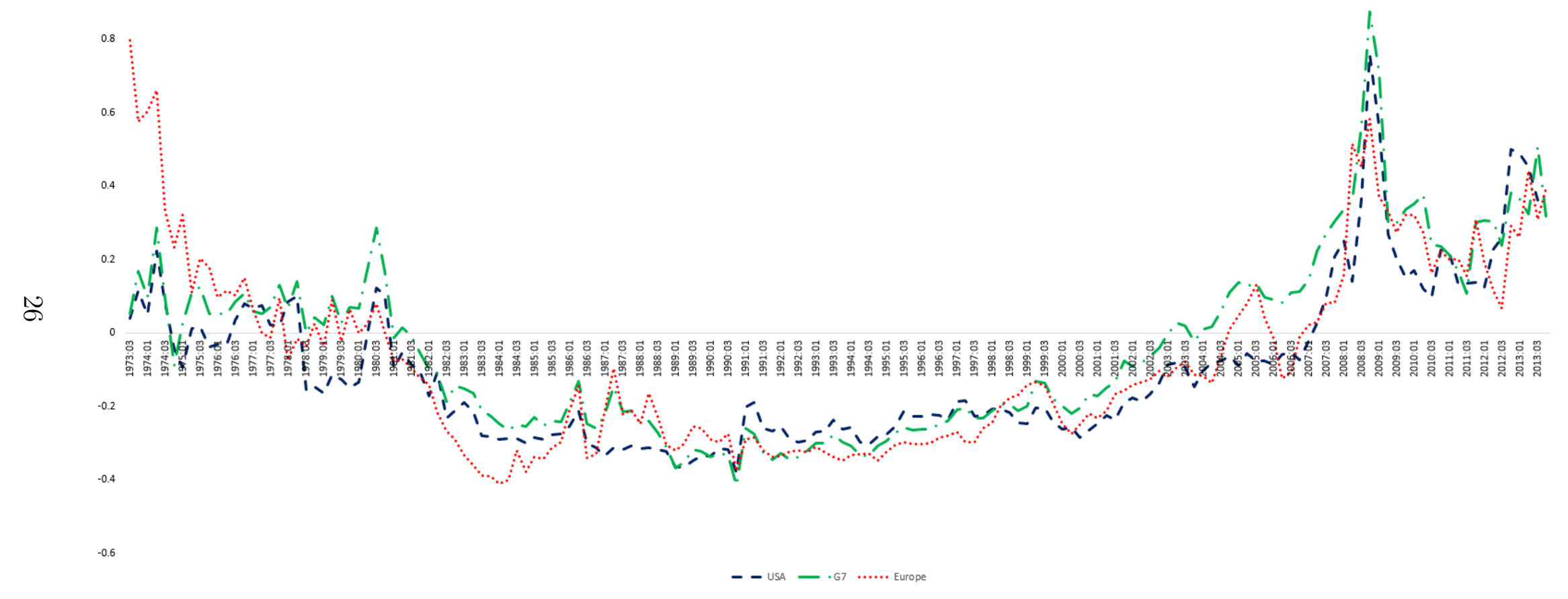

Note: A positive trace statistic indicates that Brent oil is not cointegrated with the respective GDP series. The trace statistic is scaled by the $5 \%$ critical value and generated using both recursive and backwards recursive estimation. 
Table 1: Descriptive Statistics

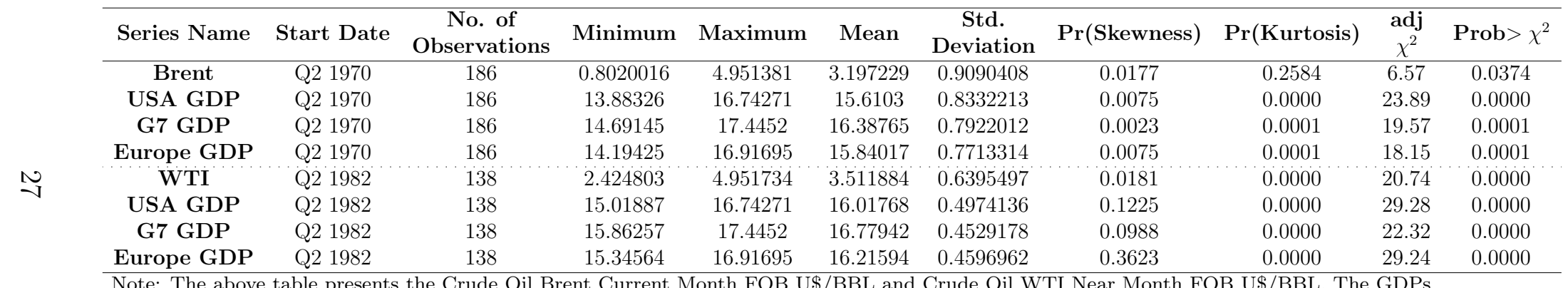

Note: The above table presents the Crude Oil Brent Current Month FOB U\$/BBL and Crude Oil WTI Near Month FOB U\$/BBL. The GDPs

shown for the United States, the G7 countries (Canada, France, Germany, Italy, Japan, the United Kingdom and the United States), and for

Europe (Austria, Belgium, Finland, France, Germany, Ireland, Italy, The Netherlands, Norway, Portugal, Spain, Sweden and the United Kingdom).

GDP represents the Gross Domestic Product calculated using the expenditure approach. All GDPs are presented in US dollars, and all are at

current prices, current PPPs, annual levels, and are seasonally adjusted. Finally, the above table gives all values after applying the natural logs

transformation. 
Table 2: Johansen (1991) Cointegration Test Results

\begin{tabular}{ccccc}
\hline & $\begin{array}{c}\text { Maximum } \\
\text { Rank }\end{array}$ & LL & $\begin{array}{c}\text { Trace } \\
\text { Statistic }\end{array}$ & $\begin{array}{c}5 \% \\
\text { Critical Value }\end{array}$ \\
\hline Brent & & & & \\
USA & 1 & 670.07953 & $7.7544^{*}$ & 12.25 \\
& 2 & 673.95673 & & \\
\multirow{2}{*}{ G7 } & 0 & 723.30544 & 41.4816 & 25.32 \\
& 1 & 739.0817 & $9.9291^{*}$ & 12.25 \\
Europe & 2 & 744.04626 & & \\
& 0 & 713.90903 & 33.6561 & 25.32 \\
& 1 & 726.09596 & $9.2823^{*}$ & 12.25 \\
\hline
\end{tabular}

\section{WTI}

\begin{tabular}{|c|c|c|c|c|}
\hline & 0 & 546.49938 & 31.6172 & 25.32 \\
\hline \multirow[t]{3}{*}{ USA } & 1 & 559.20827 & $6.1994^{*}$ & 12.25 \\
\hline & 2 & 562.30798 & & \\
\hline & 0 & 584.51911 & 33.0693 & 25.32 \\
\hline \multirow[t]{3}{*}{ G7 } & 1 & 597.81189 & $6.4837^{*}$ & 12.25 \\
\hline & 2 & 601.05376 & & \\
\hline & 0 & 556.32164 & $19.5257^{+}$ & 25.32 \\
\hline \multirow[t]{2}{*}{ Europe } & 1 & 563.12613 & 5.9168 & 12.25 \\
\hline & 2 & 566.08452 & & \\
\hline
\end{tabular}


Table 3: Bierens and Martins (2010) Test for Time-varying Cointegration

\begin{tabular}{|c|c|c|c|c|c|}
\hline & $\begin{array}{c}\text { Chebyshev } \\
\text { Time Polynomials }\end{array}$ & $\begin{array}{c}\text { Test } \\
\text { Statistic }\end{array}$ & $\begin{array}{c}10 \% \\
\text { Critical Value }\end{array}$ & $\begin{array}{c}5 \% \\
\text { Critical Value }\end{array}$ & $\begin{array}{c}\mathrm{P} \\
\text { Value }\end{array}$ \\
\hline \multicolumn{6}{|l|}{ Brent } \\
\hline \multirow{3}{*}{ USA } & $m=1$ & 1.59 & 4.61 & 5.99 & 0.45254 \\
\hline & $m=2$ & $19.32^{* *}$ & 7.78 & 9.49 & 0.00068 \\
\hline & $\mathrm{m}=4$ & $28.02^{* *}$ & 13.36 & 15.51 & 0.00047 \\
\hline \multirow{3}{*}{ G7 } & $m=1$ & 3.58 & 4.61 & 5.99 & 0.16715 \\
\hline & $m=2$ & $24.92^{* *}$ & 7.78 & 9.49 & 0.00005 \\
\hline & $\mathrm{m}=4$ & $35.00 * *$ & 13.36 & 15.51 & 0.00003 \\
\hline \multirow{3}{*}{ Europe } & $m=1$ & 1.41 & 4.61 & 5.99 & 0.49446 \\
\hline & $m=2$ & $26.39 * *$ & 7.78 & 9.49 & 0.00003 \\
\hline & $\mathrm{m}=4$ & $30.87^{* *}$ & 13.36 & 15.51 & 0.00015 \\
\hline \multicolumn{6}{|l|}{ WTI } \\
\hline \multirow{3}{*}{ USA } & $m=1$ & 8.71 & 4.61 & 5.99 & 0.01286 \\
\hline & $m=2$ & $13.53^{* *}$ & 7.78 & 9.49 & 0.00895 \\
\hline & $\mathrm{m}=4$ & $31.77^{* *}$ & 13.36 & 15.51 & 0.00010 \\
\hline \multirow{3}{*}{ G7 } & $m=1$ & $6.49^{* *}$ & 4.61 & 5.99 & 0.03892 \\
\hline & $m=2$ & $14.46^{* *}$ & 7.78 & 9.49 & 0.00597 \\
\hline & $m=4$ & $36.33^{* *}$ & 13.36 & 15.51 & 0.00002 \\
\hline Europe & $\begin{array}{l}\mathrm{m}=1 \\
\mathrm{~m}=2 \\
\mathrm{~m}=4\end{array}$ & $\begin{array}{c}\text { No } \\
\text { Cointegration }\end{array}$ & $\begin{array}{l}\text { No } \\
\text { Cointegration }\end{array}$ & $\begin{array}{c}\text { No } \\
\text { Cointegration }\end{array}$ & $\begin{array}{c}\text { No } \\
\text { Cointegration }\end{array}$ \\
\hline
\end{tabular}


Table 4: Bai and Perron (2003) Structural Break Test Results

\begin{tabular}{|c|c|c|c|c|c|c|c|c|}
\hline & Variable & Coefficient & $\begin{array}{c}\text { Std. } \\
\text { Error }\end{array}$ & $\begin{array}{c}\mathbf{T} \\
\text { Statistic }\end{array}$ & Significance & Break-point & $\begin{array}{c}\text { Lower } \\
95 \%\end{array}$ & $\begin{array}{c}\text { Upper } \\
95 \%\end{array}$ \\
\hline \multicolumn{9}{|l|}{ Brent } \\
\hline \multirow{4}{*}{ USA } & $\mathrm{DZ}(1,1)$ & 0.084 & 0.006 & 13.385 & 0 & January & February & February \\
\hline & ) & 0105 & 0.000 & 772 & 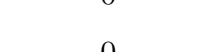 & 1974 & 1973 & 1974 \\
\hline & $\operatorname{DL}(1,2)$ & 0.195 & 0.002 & 94.173 & 0 & $\stackrel{-}{\text { March }}$ & - & $\begin{array}{c}- \\
\text { Eshor }\end{array}$ \\
\hline & DZ(1,3) & 0.261 & 0.003 & 84.978 & 0 & $\begin{array}{l}\text { March } \\
2004\end{array}$ & $\begin{array}{l}\text { March } \\
2003\end{array}$ & $\begin{array}{l}\text { February } \\
2006\end{array}$ \\
\hline \multirow{3}{*}{ G7 } & $\mathrm{DZ}(1,1)$ & 0.079 & 0.006 & 13.434 & 0 & January & February & February \\
\hline & $\mathrm{DZ}(1,2)$ & 0.186 & 0.002 & 95.134 & 0 & $\begin{array}{c}1974 \\
-\end{array}$ & $\begin{array}{c}1973 \\
-\end{array}$ & $\begin{array}{c}1974 \\
-\end{array}$ \\
\hline & $\mathrm{DZ}(1,3)$ & 0.250 & 0.003 & 85.296 & 0 & $\begin{array}{l}\text { March } \\
2004\end{array}$ & $\begin{array}{c}\text { March } \\
2003\end{array}$ & $\begin{array}{c}\text { February } \\
2006\end{array}$ \\
\hline \multirow{3}{*}{ Europe } & $\mathrm{DZ}(1,1)$ & 0.082 & 0.006 & 13.492 & 0 & January & February & February \\
\hline & $\mathrm{DZ}(1,2)$ & 0.192 & 0.002 & 95.538 & 0 & - & - & - \\
\hline & $\mathrm{DZ}(1,3)$ & 0.258 & 0.003 & 85.659 & 0 & $\begin{array}{l}\text { March } \\
2004\end{array}$ & $\begin{array}{l}\text { March } \\
2003\end{array}$ & $\begin{array}{c}\text { February } \\
2006\end{array}$ \\
\hline \multicolumn{9}{|l|}{ WTI } \\
\hline \multirow{3}{*}{ USA } & $\mathrm{DZ}(1,1)$ & 0.223 & 0.004 & 51.769 & 0 & $\begin{array}{c}\text { January } \\
1986\end{array}$ & March & February \\
\hline & $\mathrm{DZ}(1,2)$ & 0.192 & 0.002 & 99.788 & 0 & - & - & $\begin{array}{l}1900 \\
-\end{array}$ \\
\hline & $\mathrm{DZ}(1,3)$ & 0.259 & 0.002 & 113.364 & 0 & $\begin{array}{c}\text { March } \\
2004\end{array}$ & $\begin{array}{l}\text { April } \\
2003\end{array}$ & $\begin{array}{c}\text { January } \\
2005\end{array}$ \\
\hline \multirow{3}{*}{ G7 } & $\mathrm{DZ}(1,1)$ & 0.212 & 0.004 & 51.559 & 0 & $\begin{array}{c}\text { January } \\
1986\end{array}$ & $\begin{array}{c}\text { February } \\
1983\end{array}$ & $\begin{array}{c}\text { February } \\
1986\end{array}$ \\
\hline & $\mathrm{DZ}(1,2)$ & 0.183 & 0.002 & 99.372 & 0 & - & - & - \\
\hline & $\mathrm{DZ}(1,3)$ & 0.248 & 0.002 & 112.904 & 0 & $\begin{array}{l}\text { March } \\
2004\end{array}$ & $\begin{array}{l}\text { April } \\
2003\end{array}$ & $\begin{array}{c}\text { January } \\
2005\end{array}$ \\
\hline \multirow{3}{*}{ Europe } & $\mathrm{DZ}(1,1)$ & 0.219 & 0.004 & 51.797 & 0 & $\begin{array}{c}\text { January } \\
1986\end{array}$ & $\begin{array}{c}\text { February } \\
1983\end{array}$ & $\begin{array}{c}\text { February } \\
1986\end{array}$ \\
\hline & $\mathrm{DZ}(1,2)$ & 0.189 & 0.002 & 99.831 & 0 & - & - & - \\
\hline & $\mathrm{DZ}(1,3)$ & 0.256 & 0.002 & 113.426 & 0 & $\begin{array}{l}\text { March } \\
2004\end{array}$ & $\begin{array}{l}\text { April } \\
2003\end{array}$ & $\begin{array}{c}\text { January } \\
2005\end{array}$ \\
\hline
\end{tabular}

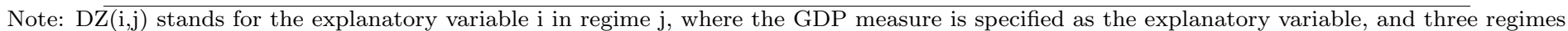
are identified matching with the two breakpoints identified. 
Table 5: Shin et al. (2014) Nonlinear ARDL Cointegration Model

\begin{tabular}{|c|c|c|c|c|c|}
\hline \multicolumn{6}{|c|}{ USA GDP \& Brent } \\
\hline \multicolumn{3}{|c|}{ Long-run Effect [+] } & \multicolumn{3}{|c|}{ Long-run Effect [-] } \\
\hline Coef. & F-stat & $\mathrm{P}>\mathrm{F}$ & Coef. & F-stat & $\mathrm{P}>\mathrm{F}$ \\
\hline-0.04500 & 0.04118 & 0.839 & 0.018 & 0.00665 & 0.935 \\
\hline \multicolumn{3}{|c|}{ Long-run Asymmetry } & \multicolumn{3}{|c|}{ Short-run Asymmetry } \\
\hline & F-stat & $\mathrm{P}>\mathrm{F}$ & & F-stat & $\mathrm{P}>\mathrm{F}$ \\
\hline & 0.04173 & 0.838 & & 13.45 & 0.000 \\
\hline \multicolumn{6}{|c|}{ USA GDP \& WTI } \\
\hline \multicolumn{3}{|c|}{ Long-run Effect $[+]$} & \multicolumn{3}{|c|}{ Long-run Effect [-] } \\
\hline Coef. & F-stat & $\mathrm{P}>\mathrm{F}$ & Coef. & F-stat & $\mathrm{P}>\mathrm{F}$ \\
\hline-0.02000 & 0.07093 & 0.79 & 0.17 & 3.711 & 0.056 \\
\hline \multicolumn{3}{|c|}{ Long-run Asymmetry } & \multicolumn{3}{|c|}{ Short-run Asymmetry } \\
\hline & F-stat & $\mathrm{P}>\mathrm{F}$ & & F-stat & $\mathrm{P}>\mathrm{F}$ \\
\hline & 28.88 & 0.000 & & 6.246 & 0.014 \\
\hline
\end{tabular}

\begin{tabular}{cccccc}
\multicolumn{3}{c}{ Long-run Effect $[+]$} & \multicolumn{3}{c}{ Long-run Effect $[-]$} \\
Coef. & F-stat & $\mathrm{P}>\mathrm{F}$ & Coef. & F-stat & $\mathrm{P}>\mathrm{F}$ \\
0.09300 & 0.5159 & 0.474 & -0.096 & 0.3856 & 0.535 \\
Long-run Asymmetry & Short-run Asymmetry \\
\multicolumn{4}{r}{ F-stat } & $\mathrm{P}>\mathrm{F}$ & \multicolumn{3}{c}{ F-stat } & $\mathrm{P}>\mathrm{F}$ \\
0.001909 & 0.965 & & 6.358 & 0.013 \\
\hline
\end{tabular}

\begin{tabular}{cccccc}
\hline \multicolumn{4}{c}{ G7 GDP \& WTI } \\
\multicolumn{4}{c}{ Long-run Effect $[+]$} & \multicolumn{3}{c}{ Long-run Effect $[-]$} \\
Coef. & F-stat & $\mathrm{P}>\mathrm{F}$ & Coef. & F-stat & $\mathrm{P}>\mathrm{F}$ \\
-0.01000 & 0.02637 & 0.871 & 0.151 & 4.368 & 0.039 \\
Long-run Asymmetry & \multicolumn{4}{c}{ Short-run Asymmetry } \\
\multicolumn{4}{c}{ F-stat } & P $>$ F & \multicolumn{4}{c}{ F-stat } & P $>$ F \\
40.71 & 0.000 & & 2.938 & 0.089 \\
\hline
\end{tabular}

\begin{tabular}{|c|c|c|c|c|c|}
\hline \multicolumn{6}{|c|}{ Europe GDP \& Brent } \\
\hline \multicolumn{3}{|c|}{ Long-run Effect $[+]$} & \multicolumn{3}{|c|}{ Long-run Effect [-] } \\
\hline Coef. & F-stat & $\mathrm{P}>\mathrm{F}$ & Coef. & F-stat & $\mathrm{P}>\mathrm{F}$ \\
\hline 0.16700 & 1.603 & 0.207 & -0.126 & 0.5924 & 0.443 \\
\hline \multicolumn{3}{|c|}{ Long-run Asymmetry } & \multicolumn{3}{|c|}{ Short-run Asymmetry } \\
\hline & F-stat & $\mathrm{P}>\mathrm{F}$ & & F-stat & $\mathrm{P}>\mathrm{F}$ \\
\hline & 0.3371 & 0.562 & & 1.433 & 0.233 \\
\hline
\end{tabular}

\begin{tabular}{cccccc}
\hline \multicolumn{4}{c}{ Europe GDP \& WTI } \\
\multicolumn{4}{c}{ Long-run Effect $[+]$} & \multicolumn{3}{c}{ Long-run Effect $[-]$} \\
Coef. & F-stat & P $>$ F & Coef. & F-stat & P $>$ F \\
0.09400 & 0.715 & 0.399 & 0.024 & 0.02698 & 0.870 \\
Long-run Asymmetry & \multicolumn{3}{c}{ Short-run Asymmetry } \\
F-stat & P $>$ F & \multicolumn{3}{c}{ F-stat } & P $>$ F \\
4.039 & 0.047 & & 0.568 & 0.452
\end{tabular}

Note: This table presents the results of the NARDL method by Shin et al. (2014), which assumes that changes in the dependent variable can be obtained by decomposing positive and negative unit changes of the independent variable around a threshold of 0 . Long-run effects refer to a permanent change of 1 in the exogenous variable. 
Table 6: Clegg and Krauss (2018) Partial Cointegration Analysis

\begin{tabular}{|c|c|c|c|c|c|}
\hline \multicolumn{3}{|c|}{ USA GDP \& Brent } & \multicolumn{3}{|c|}{ USA GDP \& WTI } \\
\hline & Estimate & Std. Err. & & Estimate & Std. Err. \\
\hline$\beta$ & 0.0114 & 0.0063 & $\beta$ & 0.0055 & 0.0063 \\
\hline$\rho$ & 0.0000 & $\mathrm{~N} / \mathrm{A}$ & $\rho$ & 0.0000 & $\mathrm{~N} / \mathrm{A}$ \\
\hline$\sigma_{M}$ & 0.0000 & $\mathrm{~N} / \mathrm{A}$ & $\sigma_{M}$ & 0.0000 & 0.0000 \\
\hline$\sigma_{R}$ & 0.0181 & 0.0009 & $\sigma_{R}$ & 0.0143 & 0.0008 \\
\hline -LL & \multicolumn{2}{|c|}{-482.79} & $-\mathrm{LL}$ & \multicolumn{2}{|c|}{-389.87} \\
\hline PVMR & \multicolumn{2}{|c|}{0.00} & PVMR & \multicolumn{2}{|c|}{0.00} \\
\hline \multicolumn{3}{|c|}{ Likelihood Ratio Test } & \multicolumn{3}{|c|}{ Likelihood Ratio Test } \\
\hline Hypothesis & Statistic & $\mathrm{p}$-value & Hypothesis & Statistic & $\mathrm{p}$-value \\
\hline Random Walk & 0.000 & 0.865 & Random Walk & -0.010 & 0.836 \\
\hline $\mathrm{AR}(1)$ & 0.000 & 0.128 & $\operatorname{AR}(1)$ & 0.000 & 0.157 \\
\hline Combined & \multicolumn{2}{|c|}{0.860} & Combined & \multicolumn{2}{|c|}{0.830} \\
\hline \multicolumn{3}{|c|}{ G7 GDP \& Brent } & \multicolumn{3}{|c|}{ G7 GDP \& WTI } \\
\hline & Estimate & Std. Err. & & Estimate & Std. Err. \\
\hline$\beta$ & 0.0139 & 0.0059 & $\beta$ & 0.0075 & 0.0056 \\
\hline$\rho$ & 0.7340 & $\mathrm{~N} / \mathrm{A}$ & $\rho$ & 1.0000 & $\mathrm{~N} / \mathrm{A}$ \\
\hline$\sigma_{M}$ & 0.0000 & $\mathrm{~N} / \mathrm{A}$ & $\sigma_{M}$ & 0.0130 & 0.0007 \\
\hline$\sigma_{R}$ & 0.0169 & 0.0009 & $\sigma_{R}$ & 0.0000 & $\mathrm{~N} / \mathrm{A}$ \\
\hline$-\mathrm{LL}$ & \multicolumn{2}{|c|}{-495.31} & -LL & \multicolumn{2}{|c|}{-404.00} \\
\hline PVMR & \multicolumn{2}{|c|}{0.00} & PVMR & \multicolumn{2}{|c|}{1.00} \\
\hline \multicolumn{3}{|c|}{ Likelihood Ratio Test } & \multicolumn{3}{|c|}{ Likelihood Ratio Test } \\
\hline Hypothesis & Statistic & $\mathrm{p}$-value & Hypothesis & Statistic & $\mathrm{p}$-value \\
\hline Random Walk & -0.060 & 0.808 & Random Walk & -0.350 & 0.629 \\
\hline $\operatorname{AR}(1)$ & 0.000 & 0.128 & $\operatorname{AR}(1)$ & 0.000 & 0.961 \\
\hline Combined & \multicolumn{2}{|c|}{0.750} & Combined & \multicolumn{2}{|c|}{0.910} \\
\hline
\end{tabular}

\begin{tabular}{|c|c|c|c|c|c|}
\hline \multicolumn{3}{|c|}{ Europe GDP \& Brent } & \multicolumn{3}{|c|}{ Europe GDP \& WTI } \\
\hline & Estimate & Std. Err. & & Estimate & Std. Err. \\
\hline$\beta$ & 0.0164 & 0.0058 & $\beta$ & 0.0102 & 0.0057 \\
\hline$\rho$ & 0.0000 & $\mathrm{~N} / \mathrm{A}$ & $\rho$ & 0.0000 & $\mathrm{~N} / \mathrm{A}$ \\
\hline$\sigma_{M}$ & 0.0000 & 0.0000 & $\sigma_{M}$ & 0.0000 & 0 \\
\hline$\sigma_{R}$ & 0.0166 & 0.0008 & $\sigma_{R}$ & 0.0131 & 0.0008 \\
\hline$-\mathrm{LL}$ & \multicolumn{2}{|c|}{-497.92} & -LL & \multicolumn{2}{|c|}{-402.94} \\
\hline PVMR & \multicolumn{2}{|c|}{0.00} & PVMR & & \\
\hline \multicolumn{3}{|c|}{ Likelihood Ratio Test } & \multicolumn{3}{|c|}{ Likelihood Ratio Test } \\
\hline Hypothesis & Statistic & p-value & Hypothesis. & Statistic & p-value \\
\hline Random Walk & -0.130 & 0.769 & Random Walk & -0.060 & 0.800 \\
\hline $\operatorname{AR}(1)$ & 0.000 & 0.128 & $\operatorname{AR}(1)$ & 0.000 & 0.158 \\
\hline Combined & \multicolumn{2}{|c|}{0.670} & Combined & \multicolumn{2}{|c|}{0.690} \\
\hline
\end{tabular}

